Check for updates

Seattle, WA, USA

bdnelson@nasw.org

Cite this as: BMJ 2020;369:m2332 http://dx.doi.org/10.1136/bmj.m2332 Published: 16 June 2020
HOSPITAL PREPAREDNESS

\section{Too little or too much? Missing the Goldilocks zone of hospital capacity during covid-19}

\begin{abstract}
Hastily constructed field hospitals in the US and UK have largely gone unused. Yet empty beds might provide important lessons on improving hospital preparedness and flexibility, writes Bryn Nelson
\end{abstract}

\section{Bryn Nelson science journalist}

The 17 March 2020 letter from Jay Inslee, the governor of Washington state, to US President Donald Trump began with an urgent request. "I am asking that you send the USS Mercy to the Puget Sound region immediately," it read.

Two models projected that the Seattle region was only a few weeks away from running out of hospital capacity due to an influx of patients with covid-19, and the Navy's hospital ship was seen as a lifeline. "It is very clear that our hospitals will be overwhelmed soon," Inslee wrote.

Nine days later, researchers at the Institute for Health Metrics and Evaluation at the University of Washington projected that demand for ventilators and beds in US intensive care units would "far exceed capacity for covid-19 patients as early as the second week of April." ${ }^{1}$ Establishing emergency field hospitals, the report said, was one way to tackle "excess need."

Over the short history of covid-19 in the US and UK, projected and real bed shortages have been recurring concerns. Six months in, however, it's clear that many planners missed the "sweet spot" of securing the right number of extra beds in the right places at the right time. Better data, funding, preparation, and flexibility, experts say, might help them avoid a repeat.

\section{The ship has sailed}

The Mercy ended up being sent to Los Angeles. But Seattle still got the emergency beds asked for by the state governor-the US Army Corps of Engineers built an emergency field hospital with 250 beds in a huge Seattle exhibition hall in early March. The field hospital was designed to handle non-covid-19 cases to free up beds elsewhere.

After a "massive infusion of new data," a rejigged model from the University of Washington released on 6 April indicated that the state had already passed its peak two days beforehand, with hospital capacity to spare. ${ }^{2}$ And on 8 April, Inslee closed the hospital before it had seen a single patient so that equipment and medical staff could be redeployed to other states. "The modelling after we implemented strict health measures convinced state officials there would be adequate hospital surge capacity by the time the spread peaked,” Inslee spokesman Mike Faulk told The BMJ in an email.
Similar scenarios played out around the country. By 11 May, US Army engineers had helped to build 37 temporary hospitals with a combined capacity of more than 15000 beds-some designed for patients however, sat empty or cared for only a few dozen patients before closing, including huge facilities in Denver, Miami Beach, Detroit, and suburban Milwaukee.

Hard hit New York City was a partial exception, where a mammoth field hospital in a convention hall and another in Central Park together treated more than 1400 patients with covid-19. But the 1000 bed USNS Comfort sent to New York Harbor with considerable pomp treated fewer than 180 patients during its three week stay. And the USNS Mercy treated just 77 patients in Los Angeles over seven weeks.

Officials across the country largely agreed that it had been good that the expensive field and ship hospitals remained mostly empty. But was it?

\section{If you build it ...}

"Well no, not in retrospect," said Irwin Redlener, director of the National Center for Disaster Preparedness at Columbia University in New York. The costly build up of largely unnecessary hospital beds, Redlener told The BMJ, partially reflected a reliance on "bad modeling based on insufficient data." That data shortfall was worsened by the "fiasco" over covid-19 testing capacity, he said.

Then again, the SARS-CoV-2 coronavirus is a new pathogen that threw the world a curveball. "There's a lot about its behavior that we couldn't possibly predict and still can't predict,” Redlener said. “And if you're the mayor or the governor, you don't want to get caught with insufficient capacity.”

Other experts were similarly circumspect. "I’m trying to think of any other part of society, when we built something or developed something and said it's a real success because we didn't get to use it," said Carl Heneghan, professor and director of the Centre for Evidence Based Medicine at Oxford University. (Heneghan is editor in chief of BMJ Evidence Based Medicine.) He compared it to having a nuclear bomb on hand that you never want to use.

Heneghan said that the UK's much publicised Nightingale hospitals were likewise sited in exhibition centres but only lightly used. "I think it's not acceptable to call things a success when actually, with covid-19 and others for non-covid cases. Most, 
you could have been using the resources and strategy and directed them to other areas where the problem existed," he said, such as care homes. "While we were building the Nightingale hospitals, we took our eye off the ball, if you like."

Rebecca Katz, director of the Center for Global Health Science and Security at Georgetown University in Washington, DC, said that she was conflicted over how to judge the ramp up in hospital capacity, given the difficulty of making decisions in an emergency filled with uncertainties. The fact that she couldn't say whether the decisions were good or bad was itself a statement on the frustrating lack of data. she said.

"The speed of the onset of the transmission of this disease in places like New York, London, Lombardy, and Madrid was so quick that nobody should be surprised that errors were made," Heneghan said. The question is whether health officials will be open to thinking through how to proceed differently the next time around.

\section{Fever hospitals}

One critical lesson in the US, Redlener said, is that hospitals were woefully underprepared for a large scale event despite years of discussions and planning after the 11 September 2001 terror attacks. In addition, he said, federal funding for hospital preparedness "has always been a fraction of what's actually needed" while public health systems likewise have been chronically underfunded.

For Katz, other key lessons are the need for flexibility in how to expand hospital capacity without shutting off other critical elements of care and the importance of a clear plan and communication around how overflow spaces will be used. "It's not enough to just set up a space," she said. "You have to integrate it into the system, and into your communication, and into your engagement with the population."

In Wuhan, China, the government built two new hospitals from scratch to treat patients with covid-19. In addition, the country used a separate strategy that resembled the US and UK plans by siting 16 temporary facilities within large existing structures such as exhibition centres and sports arenas. The Chinese strategy, though, diverged by reserving those temporary spaces solely for patients with mild to moderate covid-19. ${ }^{3}$ The hospitals, which could be assembled in as little as 29 hours, offered medical care, monitoring, and social activities to patients. The 16 facilities, built over a three week period beginning 5 February 2020, supplied 13 ooo extra beds and cared for about 12 ooo patients with covid-19 by 10 March, when the last hospital closed.

Heneghan has gone one step further and called for a revival of Britain's fever hospitals for covid-19. Fever hospitals were small permanent structures that specialised in treating patients with infectious diseases of the day, like scarlet fever, smallpox, and typhus. ${ }^{4}$ More than just separate structures providing extra capacity, he said, intermediate infection hospitals could offer an effective and overarching strategy of training staff in infection control and diverting patients who need intermediate care for infectious diseases like covid-19 and influenza away from main hospitals full of other vulnerable patients.

As for the cost, Heneghan maintained that the investment would be "minuscule" compared with the cost of not doing it and then vastly underestimating demand during a second covid-19 wave or future outbreak. The lack of infrastructure could overwhelm health systems, he said, once again forcing officials to respond by shutting down society.
Competing interests: I have read and understood BMJ policy on declaration of interests and have no relevant interests to declare.

1 Institute for Health Metrics and Evaluation. New covid-19 forecasts: US hospitals could be overwhelmed in the second week of April by demand for ICU beds, and US deaths could total 81000 by July. 26 March 2020. http://www.healthdata.org/news-release/new-covid-19-forecastsus-hospitals-could-be-overwhelmed-second-week-april-demand-icu

2 Doughton S. New UW analysis lowers coronavirus death projections and suggests hospitalizations may have already peaked in Washington. Seattle Times 2020;6: https://www.seattletimes.com/seattle-news/health/new-uw-analysis-lowers-coronavirus-death-projections-andsuggests-hospitalizations-may-have-already-peaked-in-washington/.

3 Chen S, Zhang Z, Yang J, etal. Fangcang shelter hospitals: a novel concept for responding to public health emergencies. Lancet 2020;395:1305-14. doi: 10.1016/S0140-6736(20)30744-3. pmid: 32247320

4 Jefferson T, Heneghan C. Covid-19: fever hospitals. 11 May 2020. https://www.cebm.net/covid19/covid-19-reestablishing-fever-hospitals/

This article is made freely available for use in accordance with BMJ's website terms and conditions for the duration of the covid-19 pandemic or until otherwise determined by BMJ. You may use, download and print the article for any lawful, non-commercial purpose (including text and data mining) provided that all copyright notices and trade marks are retained. 